\title{
The Impact Of Carbon Tax On Financial And Sustainability Reporting In South Africa: The Case Of Motor Vehicle Manufactures
}

Suren Pillay, South African Revenue Service (SARS), South Africa

Pieter Buys, North West University, South Africa

\begin{abstract}
Sustainability reporting in South Africa has emerged strongly in the last decade with evidence suggesting that corporate social responsibility assurance prevalence is growing among the top 100 publicly-listed companies. Multinational motor vehicle manufacturers will have to comply with all sustainable reporting requirements that incorporate South African motor vehicle subsidiary company results. Carbon excise tax was implemented on all passenger motor vehicles on 1 September, 2010 in South Africa. From an accounting perspective, the adequacy of carbon tax recognition and disclosures has not been assessed in South Africa.
\end{abstract}

This paper examines the adequacy of carbon tax accounting disclosures by local motor vehicle manufacturers that are subject to such a tax as well as the compliance level of the related multinational motor vehicle holding companies in terms of sustainable reporting.

Keywords: Accounting; Carbon Taxation; Climate Change; Corporate Social Responsibility; Sustainable Development; Sustainability Reporting

\section{INTRODUCTION}

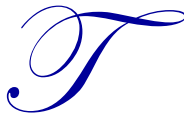

he concept of sustainable development has been defined as that which is required to harmonise the fulfilment of human needs with the protection of the natural environment, so that these needs can be met not only in the present, but in the indefinite future (Mohammed, 2011). Furthermore, sustainable development also comprises various elements categorised in three primary dimensions - the environmental, economic, and social dimensions (EEA GRANTS, 2006). These three dimensions constitute the so-called triple bottom line (TBL), which has been defined as the balance of sustainability for three different performance aspects; namely, environmental, economic, and social performance aspects (Newport et al., 2003). The TBL concept brought into being the notion that organisations were starting to think about issues related to sustainable development and needed to move away from a single financial bottom line as the key corporate objective, to a recognition that organisations also have social and environmental bottom lines (Gray \& Milne, 2002). A sustainability report, therefore, is a holistic organisational report that provides information about the relevant economic, environmental, social (including governance) performances (GR, 2013). One organisation that promotes sustainable development in the area of sustainability reporting is the Global Reporting Initiative (GRI), which provides a sustainability reporting framework that can be applied practically to issues of sustainable development (GRI, 2012a). Closely linked to sustainability reporting is also the Carbon Disclosure Project (CDP), which is an international non-profit organisation providing the only international system for companies to measure and disclose important environmental data and, according to the CDP (2013), holds the largest collection of climate change as well as water and forest risk information from a global perspective. 
In terms of accounting for sustainable development, there is a need for the costs and benefits of environmental and social matters to be identified, as well as for the measurement and quantification of these costs and benefits where appropriate (Aras \& Crowther, 2009). In terms of sustainable development and TBL reporting, external corporate social responsibility (CSR) assurance provides stakeholders with assurances that the applicable CSR disclosures may be relied upon. Furthermore, in South Africa, there is also strong evidence that such CSR assurance prevalence is growing among the top 100 publicly-listed companies (Ackers, 2009). Internationally, the reporting of corporate responsibility (CR) activities is also growing rapidly with a KPMG international survey indicating that approximately $95 \%$ of the 250 largest companies in the world reported on its CR activities in 2011, which represents a substantial improvement on the approximately 81\% of such companies in 2008 (SAICA, 2013a). In South Africa, the provision of integrated reports (in essence, combining the sustainability report and financial statements) has become a listing requirement of the Johannesburg Securities Exchange Ltd (JSE) for financial years starting on or after 1 March 2010 (SAICA, 2013a).

Linked to sustainability reporting specifically in South Africa is the Social Responsible Index (SRI), which was launched by the JSE as the first socially responsible investment index containing a listing of companies on the FTSE/JSE All Share Index that have met certain criteria in respect of TBL performances (JSE, 2012). According to the annual 2011 SRI index review, approximately two-thirds of the JSE-listed companies had fulfilled the requirement to become a constituent of the JSE's SRI index as at December 2011 (SSA, 2011).

\section{FINANCIAL ACCOUNTING AND REPORTING OF CARBON TAX}

Supportive to the concept of sustainability are the various instruments designed to enhance sustainable development, such as carbon tax, which is a market-based instrument that creates a direct cost to emissions by taxing the carbon content of fuels (Hasset et al., 2007). The purpose of carbon tax is to internalise externalities related to anthropogenic climate change (Metcalf, 2009) as well as assisting in controlling the problem of global warming caused by increasing concentrations of greenhouse gases (Pearson \& Smith, 1991). According to Clarke (2011), carbon tax, which was first introduced in Europe in the early 1990's, has been widely advocated as a means of reducing such emissions to address anthropogenic climate change.

Financial reporting is typically conducted in accordance with International Financial Reporting Standards (IFRS) as promulgated by the International Accounting Standards Board (IASB) (IFRS, 2013). It should be noted that from 1973 until 2000, a series of accounting standards, known as the International Accounting Standards (IAS), was released by the International Accounting Standards Committee (IASC), a body that was replaced by the International Accounting Standards Board (IASB) in 2001 (ICAEW, 2013). From a South African perspective, as from 2005, the JSE requires all South African-listed companies to comply with IFRS (Kinsey, 2006). The historical 'South African Generally Accepted Accounting Practices' (SA GAAP) have therefore also been completely harmonised with the IFRS. Following the letter of the law, however, South African unlisted companies are not compelled to produce financial statements in accordance with IFRS, but should still comply with either 1) SA GAAP or 2) if they meet the Small or Medium Entity (SME) criteria with the IFRS for SMEs (SAICA, 2013b).

Per a comparison report of the full IFRS standards and the IFRS for SMEs, it was noted that the recognition and measurement requirements, in respect of account balances that relate to carbon tax such as revenue, inventory, as well as liabilities, were not different under either IFRS or IFRS for SMEs (PWC, 2013). Since SA GAAP is fully harmonised with full IFRS (SAICA, 2013b), and since there is no difference in carbon tax reporting requirements between IFRS for SMEs and full IFRS (PWC, 2013), it essentially means that whether an unlisted/private entity prepares financial statements in accordance with 1) SA GAAP or 2) IFRS for SMEs, such financial statements would still have to be indirectly in compliance with full IFRS in respect of any relevant carbon tax transactions and disclosures.

\section{PROBLEM STATEMENT, OBJECTIVES, AND RESEARCH METHOD}

The implementation of carbon excise tax in South Africa triggered the interpretation and application of IFRS in the financial statements of South African motor vehicle manufacturers. The implementation of carbon tax may therefore also affect the carbon emission reduction strategy of motor vehicle manufacturers as disclosed in their sustainability reports. The primary research question under consideration could therefore be formulated in two parts: 
- $\quad \mathrm{P}_{1}$ : Has the carbon tax been correctly accounted for and disclosed in the financial statements of South African motor vehicle manufacturers in accordance with IFRS?

- $\quad \mathrm{P}_{2}$ : Have the necessary carbon emission disclosures been made in the sustainability reports of these motor vehicle manufacturers?

This study comprised both literature and empirical sections. With regard to the literature section, a detailed review will be conducted in two stages. In the first stage, the history and evolution of sustainable reporting are considered to set the background for the study; while in the second stage, the level of sustainable reporting in South Africa is considered with a specific focus on the motor vehicle manufacturing industry. The level of GRI compliance is also considered among South African companies and then especially in the motor vehicle manufacturing industry.

An empirical research study will also be performed to explore the accounting treatment of carbon tax by motor vehicle manufacturers in South Africa. The overall targeted population was the eight multinational vehicle manufacturers producing/assembling motor vehicles in South Africa. It should be noted that Renault and Nissan entered into a global alliance agreement, which effectively results in them becoming 'one manufacturer' in the South African context (Anon, 2013). The exploratory research questionnaire was developed based on the underlying literature study (as mentioned above) and consisted of 11 questions utilising an appropriate Likert-type response scale in certain questions, or a description and explanation of the accounting treatment of carbon tax in the applicable reports statements. The researcher was available during the survey to provide guidance and clarification should the respondents have experienced uncertainties with regard to the questionnaire. The structured questionnaire had three objectives; namely, 1) to determine the issues or complexities around the issue of carbon tax reporting, 2) to gauge the actual accounting treatment of carbon tax in terms of IAS 18 (Revenue) and IAS 37 (Provisions and Liabilities), and 3) to understand the rationale behind the current accounting treatment of carbon tax as per the industry.

In order to reach the objectives of this article, some consideration is given to the growth of sustainability reporting, from the initial developments thereof, evolving into the South African context hereof per industry grouping and then also for the motor vehicle manufacturing industry specifically. Secondly, the accounting treatment of carbon taxes within the context of IFRS is considered. Thirdly, the applicable responses received from the respondents in terms of their disclosures and treatment are analyzed and some closing discussion and conclusions are presented.

\section{THE GROWTH OF SUSTAINABLE REPORTING}

According to Gray and Milne (2002, p. 3), the emergence of the TBL was a good idea as it allowed for full accountability and that an organisation needed to deliver a full set of social and environmental statements alongside its regular financial statements. In addition, the advent of sustainable development resulted in increasing stakeholder interests in corporate responsibility, with many companies having converted their corporate environmental reports (CERs) into full-blown corporate sustainability reports (CSRs) and by integrating accounting aspects on environmental, social and economic issues into their TBL reporting (Hedberg \& Von Malmborg, 2003).

In terms of the motivation for sustainable reporting, a study conducted in Ireland revealed that many senior executives are of the opinion that the prime motive for embarking on a sustainable reporting initiative was to improve or enhance its own corporate legitimacy (Adams \& McNicholas, 2007). In support hereof, Bebbington et al. (2009, p. 615) state that the primary reasons for companies initiating sustainability reporting are typically a mix of legitimacy and accountability motivations in which the company will embark on such reporting initiatives when various factors intersect. Sustainability reports have been evolving over time and an increase in efforts to advance the specific business case for sustainability, including attempts to provide measurable economic outcomes from various sustainable activities and initiatives, was noted (Bowers, 2010). The impact of mandatory sustainability reporting has, according to Iannou and Serafeim (2011), also been examined on management practices, with a conclusion that mandatory sustainability reporting had a role in the increase in the social responsibility of business leaders, the prioritisation of sustainable development initiatives, and an increase in the implementation of ethical practices by firms. 
In terms of sustainability reporting, a detailed research study comprising of 392 GRI reports submitted by South African companies found South African sustainability reporting to be the fifth highest in the world based on the number of GRI reports submitted (CSAP, 2013). Figure 1 provides a summary indication of sustainability reporting by industry in South Africa in 2011. Industry compliance denoted by percentages on the vertical axis reflects the number of company GRI reports submitted in an industry relative to the total number of company GRI reports that should have been submitted in the industry.

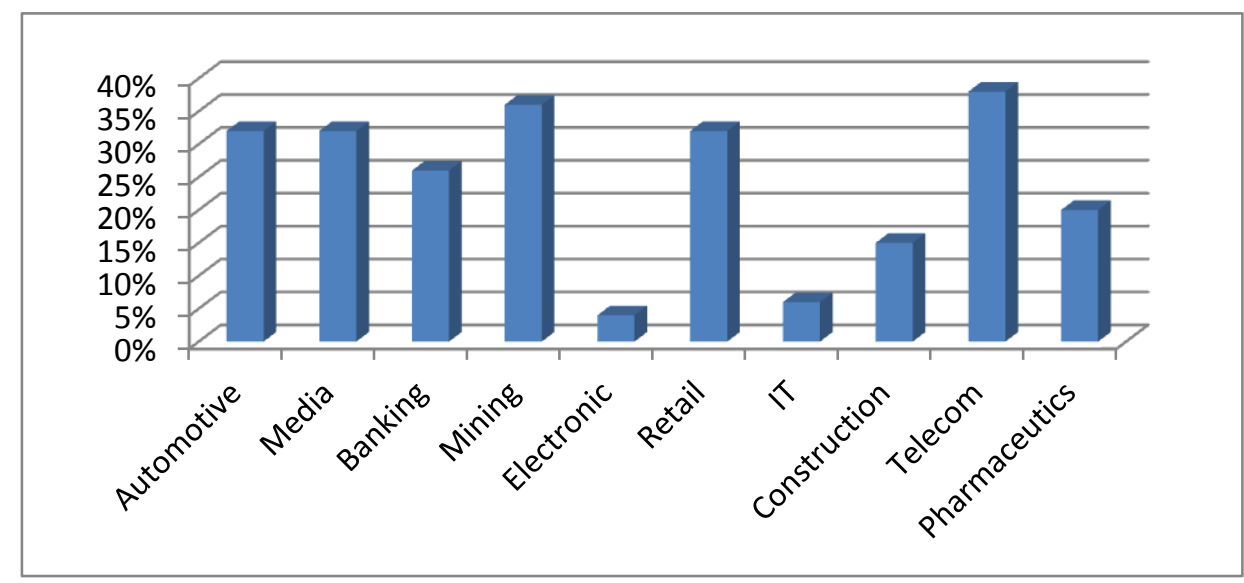

Figure 1: Sustainability Reporting by Industry: 2011

Source: Adapted from CSAP, 2013

As per Figure 1, the leading industries in sustainability reporting are mining (approximately 36\%) and telecommunications (approximately 38\%), while the IT (approximately 6\%) and electronic (approximately 4\%) industries represent the poorest compliance levels in South Africa. In terms of sustainability reporting of motor vehicle manufacturers, it should be noted that there are eight multinational motor vehicle companies in South Africa (SANEA, 2010). The levels of sustainability reporting compliance of these companies are summarised in Table 1.

Table 1: Sustainability Reporting Compliance by Motor Vehicle Manufacturers

\begin{tabular}{|l|c|c|c|c|c|c|}
\hline No & Name & $\begin{array}{c}\text { Sustainable } \\
\text { Report Submitted }\end{array}$ & $\begin{array}{c}\text { Last Year } \\
\text { Submitted }\end{array}$ & $\begin{array}{c}\text { GRI Report } \\
\text { Format }\end{array}$ & $\begin{array}{c}\text { GRI } \\
\text { Checked }\end{array}$ & $\begin{array}{c}\text { Carbon Disclosures } \\
\text { Included }\end{array}$ \\
\hline 1 & Toyota & Yes & 2012 & Non-GRI & No & Yes \\
\hline 2 & VW & Yes & 2011 & G3 & Yes & Yes \\
\hline 3 & Nissan & Yes & 2012 & GRI Referenced & No & Yes \\
\hline 4 & BMW & Yes & 2010 & G3 & Yes & Yes \\
\hline 5 & Daimler & Yes & 2011 & G3.1 & Yes & Yes \\
\hline 6 & General Motors & Yes & 2011 & G3.1 & No & No \\
\hline 7 & Renault & Yes & 2010 & G3 & No & No \\
\hline 8 & Ford & Yes & 2011 & G3 & No & Yes \\
\hline
\end{tabular}

Source: Toyota Motor Corporation, 2012; VW AG, 2012; Nissan Motor Corporation, 2012; BMW, 2012, Daimler 2012, General Motors, 2012, Renault, 2012, Ford Motor Company, 2012

The results of Table 1 indicate that even though all the manufacturers produced sustainability reports, only three (38\%) of the reports were verified by the GRI. Given that the objective of carbon tax is to address the problem of global warming (Pearson \& Smith, 1991), one would expect to note behavioural changes, such as carbon reduction strategies, in place by multinational motor vehicle manufacturers if such a tax is to be considered effective. The companies' sustainability reports were therefore inspected for disclosures regarding actions and processes in place to reduce their carbon footprint. In terms of carbon disclosures, only Renault and General Motors have not included carbon disclosures relating to actions in place to reduce carbon emissions. Per inspection of the 2011 report for Renault, it was noted that Renault and Nissan entered into a global alliance agreement, which effectively results in them becoming 'one manufacturer' within the South African context (Anon, 2013). Since Renault's compliance is being considered under Nissan's sustainability report, this leaves only General Motors. General Motors, however, has confirmed in their sustainability report that these disclosures have been made 
separately in their carbon disclosure report. It should be noted that of the manufacturers operating in South Africa, only Toyota has submitted a sustainability report in a non-GRI format.

\section{ACCOUNTING FOR CARBON TAX}

An excise tax is a particular type of tax that is ordinarily levied on certain services and products (FASB, 2013). As carbon tax is levied on the purchase price of a motor vehicle (Shirley, 2010), it should therefore be regarded as an excise tax for the purposes of financial accounting. As stated earlier, financial accounting and reporting are governed by IFRS, which is a group of accounting standards prepared by the IASB. The two specific IFRS standards that may be applicable to excise taxes are 1) IAS 18: Revenue and 2) IAS 37 Provisions, Contingent Liabilities and Contingent Assets. It should be noted that IAS 12: Income Taxes deals specifically with the accounting treatment of income tax and does not consider excise taxes (Deloitte, 2013).

Under IFRS, taxes other than income taxes are accounted for under IAS 37 (Ernst \& Young, 2012) and, in terms of this standard, a provision for such tax should be recognised when (IFRS, 2013a):

- $\quad$ an entity has a present obligation (legal or constructive) as a result of a past event

- it is probable that an outflow of resources embodying economic benefits will be required to settle the obligation

- $\quad$ a reliable estimate can be made of the amount of the obligation

A key consideration in terms of IAS 37 would therefore be whether motor vehicle manufacturers have correctly raised an accounting liability for the carbon excise tax in their financial statements. Since the excise tax can be passed on to a customer in a revenue transaction, it may be argued, however, that the transaction should be recognised in accordance with IAS 18: Revenue at the fair value of the consideration received or receivable (Ernst \&Young, 2012). In terms of IAS 18, revenue from the sale of goods shall be recognised when all the following conditions have been satisfied (EU, 2013c):

- The entity has transferred to the buyer the significant risks and rewards of ownership of the goods

- The entity retains neither continuing managerial involvement to the degree usually associated with ownership nor effective control over the goods sold

- $\quad$ The amount of revenue can be measured reliably

- It is probable that the economic benefits associated with the transaction will flow to the entity

- The costs incurred, or to be incurred in respect of the transaction, can be measured reliably

When interpreting the provisions of IAS 18, one may conclude that as the carbon tax is recovered from a customer in a revenue generating transaction, it must be included in revenue.

An alternative view, however, is expressed in a technical publication by Ernst \& Young (2012) which argues that the revenue treatment is based on whether the applicable company subject to carbon tax is acting as a principal or as an agent in the transaction with the excise tax being excluded from revenue if the local vehicle manufacturer is acting as agent. Therefore, a key question in IAS 18 is whether motor vehicle manufacturers consider themselves as an agent or as a principal and choose to recognise carbon tax in revenue for accounting purposes accordingly.

\section{EMPIRICAL RESULTS}

In terms of whether the respondents are in compliance with accepted accounting practices and standards, the sections that follow consider the responses received in terms of their compliance to IFRS. Please refer to the annexure for the detailed guiding questions put to the respondents.

\section{IFRS compliance}

Questions 1 and 2 of the questionnaire focused on the overall IFRS compliance of motor vehicle manufacturers in South Africa. Question 1 asked the respondents to rate their compliance with IFRS on a scale of 1 
to 7 and Question 2 asked the respondents on what date they converted financial preparation adoption to the IFRS format.

- Question 1: All the respondents confirmed that they are fully compliant with IFRS and indicated an average score of 7 on this question.

- Question 2: The majority of the respondents confirmed that they implemented IFRS when it was introduced, which was 2004.

\section{Carbon Tax Compliance and Process}

Questions 3 and 4 focused on the overall carbon tax compliance and processes in place in levying carbon tax on motor vehicles manufactured in South Africa. Question 3 asked the respondents whether they levy carbon tax on all newly manufactured motor vehicles in compliance with carbon tax legislation and Question 4 required the respondents to explain the process of determining the carbon tax to be levied on motor vehicles.

- $\quad$ Question 3: All the respondents confirmed that they levy carbon tax on all newly manufactured vehicles in accordance with carbon tax legislation.

- Question 4: Processes in levying carbon tax varied between respondents, with some confirming that carbon tax is levied at the point of entry into South Africa for imports and others confirming that carbon tax is paid in accordance with the Customs and Excise Act (1964). The respondents further confirmed that carbon tax is included in the selling price to dealers, excluding dealers in BLNS countries (Botswana, Lesotho, Namibia, and Swaziland), and that separate emission limits exist for passenger motor vehicles and double cabs. A rand value is associated with every gram of carbon emission exceeding the prescribed limits.

\section{IFRS Compliance of Carbon Tax Transactions}

Questions 5 to 8 focused on the overall IFRS treatment and compliance of carbon tax transactions. Question 5 asked respondents to confirm whether all sales transactions are subject to carbon tax, while Question 6 asked whether accounting personnel understand IFRS requirements relating to carbon tax. Question 7 asked whether IFRS is applied consistently to all sales transactions that are subject to carbon tax and Question 8 asked whether carbon tax has been adequately disclosed in terms of IFRS.

- $\quad$ Question 5: The majority of the respondents confirmed that sales transactions are subject to carbon tax.

- Question 6: All of the respondents confirmed that accounting personnel understand IFRS requirements relating to carbon tax.

- Question 7: All of the respondents confirmed that carbon tax is applied consistently to all sales transactions.

- Question 8: The majority of the respondents confirmed that carbon tax is adequately disclosed in terms of IFRS. The remaining respondent confirmed that there is no separate IFRS disclosure requirement for carbon tax, thereby also indicating automatic compliance with IFRS.

It was noted, per a review of IAS 18 (Revenue recognition), IAS 37 (Provisions Contingencies and Liabilities), and IAS 2 (Inventories), that there are no specific disclosure requirements relating to excise tax or carbon excise tax in particular (EU 2013a; EU 2013b; EU 2013c).

\section{Accounting Treatment of Carbon Tax}

Questions 9, 10, and 11 of the questionnaire dealt with the specific accounting treatment adopted by motor vehicle manufacturers with respect to carbon tax. Question 9 asked the respondents to describe the economic substance of carbon tax transactions that form the basis of accounting treatment, while Question 10 asked to provide the journal entries (including narrations) for the recording of carbon excise taxes. Question 11 asked the respondents whether they believe that the accounting treatment applied to carbon tax is correct in terms of IFRS. 
- $\quad$ Question 9: The majority of the respondents confirmed that the economic substance of the transaction is similar to a custom or excise tax.

- $\quad$ Question 10: An analysis of journal entries provided by the respondents confirmed that they all have raised a liability for carbon excise tax. All the respondents have also excluded carbon tax from revenue, indicating the view that motor vehicle manufacturers act as an agent rather than principal on collecting carbon tax. The view is supported by the fact that local vehicle manufacturers are required to pay over the carbon tax to SARS as evidenced by SARS revenue collection from carbon tax (Department of National Treasury \& South African Revenue Service, 2012). The accounting treatment to therefore exclude carbon tax from revenue is viewed as technically correct in terms of IFRS.

- $\quad$ Question 11: All of the respondents are of the opinion that the accounting treatment applied to carbon tax is correct in terms of IFRS.

\section{DISCUSSION AND CONCLUSION}

This paper had two important aims in mind. The first dealt with the compliance level of sustainability reports produced by multinational motor vehicle manufacturers, while the second dealt with the accounting treatment of carbon tax. In terms of sustainability reporting, the results revealed that all the multinational motor vehicle companies produce sustainability reports. All the multinational motor vehicle manufacturers also disclosed actions to reduce the carbon footprint, with the exception of General Motors, which disclosed this information under its carbon disclosure report.

The accounting treatment of carbon tax was subject to empirical study and the first enquiry was to determine the level of IFRS compliance among motor vehicle manufacturers. All the respondents considered themselves to be compliant with the majority confirming implementation of IFRS in 2004, which was when it was first introduced. All the respondents also confirmed that they levy carbon tax on all newly manufactured vehicles in accordance with carbon tax legislation and described processes in place to ensure compliance with carbon tax legislation. Furthermore, all of the respondents confirmed that their accounting personnel understood the applicable IFRS requirements relating to carbon tax and that carbon tax is applied consistently to all sales transactions. The majority of respondents also confirmed that sales transactions are subject to carbon tax and are adequately disclosed in terms of IFRS.

The actual accounting treatment of carbon tax was examined via a review of journal entries passed by the motor vehicle manufacturers to record carbon tax. All the respondents correctly raised a liability for the carbon excise tax in terms of IAS 37 and also excluded carbon tax from revenue in terms of IAS 18 under the view that motor vehicle manufacturers act as agents and not principals in collecting carbon tax. The correctness of the accounting treatment applied is reinforced by the motor vehicle manufacturers' opinion that their accounting treatment of carbon tax is correct in terms of IFRS.

\section{LIMITATIONS AND FUTURE RESEARCH}

Notwithstanding the fact that there are few motor vehicles manufactures in South Africa, the sample size of the motor vehicle manufacturers that participated in the study could be seen as a limitation. The possibility that the respondents are not representative of all multinational motor vehicle manufacturers in South Africa could not be ruled out. As most of the motor vehicle manufacturers in South Africa operate as private companies, there was no pressure on these companies to produce sustainability reports in comparison to listed companies.

Future research opportunities could include identifying countries where motor vehicle excise tax has been levied and examining the compliance of corporate entities situated in such countries with IFRS.

\section{AUTHOR INFORMATION}

Suren Pillay is a Chartered Accountant (SA) and worked at the Large Business Center section of the South African Revenue Service (SARS) KwaZulu Natal during the course of this research. This article is based on the research conducted for his PhD degree in Taxation at the North-West University in South Africa's Potchefstroom campus. 
Professor Pieter W Buys is currently the Research Program Leader at the North-West University (South Africa) and holds two PhDs (Accountancy and Management Accountancy), two Masters Degrees (MComm and MBA), and he is also a US Certified Management Accountant (CMA). E-mail: pieter.buys@nwu.ac.za (Corresponding author)

\section{REFERENCES}

1. Anon. (2013). Key facts of the Renault-Nissan alliance. Retrieved 5 Oct. 2013 from http://www.renault.com/en/Groupe/l-alliance-renault-nissan/Pages/l-alliance-renault-nissan.aspx

2. Ackers, B. (2009). Corporate social responsibility assurance: how do South African publicly listed companies compare? Meditari Accountancy Research, 17(2), 1-17.

3. Adams, C. A., \& McNicholas, P. (2007). Making a difference: sustainability reporting, accountability and organisational change. Accounting, Auditing \& Accountability Journal, 20(3), 382-402.

4. Aras, G., \& Crowther, D. (2009). Corporate sustainability reporting: A study in disingenuity. Journal of Business Ethics Supplement, 87(1), 279-288.

5. Bebbington, J., Higgins, C., \& Frame, B. (2009). Initiating sustainable development reporting: Evidence from New Zealand. Accounting, Auditing \& Accountability Journal, 22(4), 588-625.

6. Bowers, T. (2010). From image to economic value: a genre analysis of sustainability reporting. Corporate Communications: An International Journal, 15(3), 249-262.

7. $\quad$ BMW. (2012). BMW group sustainable value report 2011. Germany. 130p.

8. CDP. (2013). Driving sustainable economies. Retrieved 31 Dec. 2013 from https://www.cdproject.net/enUS/Pages/HomePage.aspx

9. $\quad$ Clarke, H. (2011). Some basic economics of carbon taxes. The Australian Economic Review, 44(2), 123136.

10. CSAP. (2013). King 3 and the GRI +12: A 2011 review of sustainable reporting in South Africa. Retrieved 14 April 2013 from http://www.csap.co.za/Documents/Research/King_III_and_GRI_12_

Research_Report.pdf

11. Daimler. (2011). Daimler sustainability report 2011. Germany. 120p.

12. Deloitte. (2013). IAS 12: Income Taxes. Retrieved 21 April 2013 from http://www.iasplus.com/en/ standards/standard 11

13. EEA Grants. (2006). Sustainable development. Policy and guide for the EEA (European Economic Area) financial mechanism and the Norwegian financial mechanism. Retrieved 10 Sept. 2011 from www.eeagrants.org/asset/341/1/341_1.pdf

14. Ernst \& Young. (2012). Implementing the medical device and excise tax. Technical Line, 11(1), 1-8.

15. EU. (2013a). International Accounting Standard 2: Inventories. Retrieved 9 Aug. 2013 from http://ec.europa.eu/internal_market/accounting/docs/consolidated/ias2_en.pdf

16. EU. (2013b). International Accounting Standard 37: Provisions, contingent liabilities and contingent assets. Retrieved 9 Aug. 2013 from http://ec.europa.eu/internal_market/accounting/docs/consolidated/ ias37_en.pdf

17. EU. (2013c). International Accounting Standard 18: Revenue. Retrieved 9 Aug. 2013 from http://ec.europa.eu/internal_market/accounting/docs/consolidated/ias18_en.pdf

18. FASB (Financial Accounting Standards Board). (2006). How sales taxes collected from customers and remitted to governmental authorities should be presented in the income statement (That is, gross versus net presentation). (FASB Emerging Issues Task Force Document: Issue Summary No.1)

19. Ford Motor Company. (2011). Ford Sustainability 2011-2012. Retrieved 7 April 2013 from http://corporate.ford.com/microsites/sustainability-report-2011-12/default

20. General Motors. (2011). Sustainability in motion. Retrieved 7 April 2013 from http://gmsustainability.com

21. Gray, R., \& Milne, M. (2002). Sustainability reporting: Who's kidding whom?' Chartered Accountants Journal of New Zealand, 81(6), 66-70.

22. GRI. (2012). About GRI. Retrieved 10 March 2012 from https://www.globalreporting.org/Information/ about-gri/Pages/default.aspx

23. GR. (2013). About sustainability reporting. Retrieved 1 April 2013 from https://www.globalreporting.org/ information/sustainability-reporting/Pages/default.aspx 
24. Hasset, K. A., Aparna, M., \& Metcalf, G. E. (2007). The incidence of U.S Carbon tax: A lifetime and regional analysis. (Working Paper 13554 prepared for the United States National Bureau of Economic Research). 42p.

25. Hedberg, C. J., \& von Malmborg, F. (2003). The global reporting initiative and corporate sustainability reporting in Swedish companies. Corporate Social Responsibility and Environmental Management, 10(3), 153-164.

26. ICAEW. (2013). Knowledge guide to international accounting standards. Retrieved 21 April 2013 from http://www.icaew.com/en/library/subject-gateways/accounting-standards/knowledge-guide-tointernational-accounting-standards

27. IFRS. (2013a). IFRS FAQ's. Retrieved 2 April 2013 from http://www.ifrs.com/ifrs_faqs.html\#q1

28. IFRS. (2013b). IAS 37 Provisions, Contingent liabilities and contingent assets. Retrieved 8 Oct. 2013 from http://www.ifrs.org/IFRSs/Documents/English\%20IAS\%20and\%20IFRS\%20PDFs\%202012/IAS\% 2037.pdf

29. Ioannou, I., \& Serafeim, G. (2011). The consequences of mandatory corporate sustainability reporting. (Harvard Business School Research Working Paper 11-100).

30. JSE. (2012). Introduction to SRI Index. Retrieved 31 Dec. 2012 from http://www.jse.co.za/Products/SRI.aspx

31. Kinsey, J. P. (2006). Developing countries converging with developed-country accounting standards: Evidence from South Africa and Mexico. The International Journal of Accounting, 41(2), 141-162.

32. Metcalf, G. E. (2009). Market based policy options to control US greenhouse gas emissions. Journal of Economic Perspectives, 23(2), 5-27.

33. Mohammed, N. (2011). Environment and sustainable development in Bangladesh: A legal study in the context of international trends. International Journal of Law and Management, 53(2), 89-107.

34. Nissan Motor Corporation. (2012). Nissan sustainability report 2012. Japan. 18p.

35. Newport, D., Chesnes, M., \& Lidner, A. (2003). The environmental sustainability problem ensuring that sustainability stands on three legs. International Journal of Sustainability in Higher Education, 4(4), 357363.

36. National Treasury \& South African Revenue Service. (2012). 2012 tax statistics. Pretoria: Government Printer. 185p.

37. Pearson, M., \& Smith, S. (1991). The European carbon tax: An assessment off the European Commission's proposals. London: The Institute for Fiscal Studies. 62p.

38. PWC. (2013). Similarities and differences A comparison of "full IFRS" and IFRS for SMEs. Retrieved 7 Oct. 2013 from http://www.pwc.com/gx/en/ifrs-reporting/pdf/Sims_diffs_IFRS_SMEs.pdf

39. $\quad$ Renault. (2012). The Renault Nissan Alliance -Nissan Sustainability Report 2011. Japan. 2p.

40. SAICA. (2013a). Sustainability reporting and integrated reporting. Retrieved 1 April 2013 from https://www.saica.co.za/TechnicalInformation/SustainabilityandIntegratedReporting/SustainabilityReportin gandIntegratedReporting/tabid/1653/language/en-ZA/Default.aspx

41. $\quad$ SAICA. (2013b). IFRS/Statements of GAAP FAQ's. Retrieved 21 April 2013 from http://www.saica.co.za/faqs/showAnswer.asp?FaqQuestionId=3460

42. SANEA. (2010). BMW South Africa brief history and overview. Retrieved 2 January 2013 from http://www.sanea.org.za/CalendarOfEvents/2010/TechnicalVisitPRETORIA/Oct28/BMW\%20South\%20A frica\%20-\%2028\%200ctober\%202010.pdf

43. Shirley, B. (2010). South Africa: Carbon tax to add thousands to cars.' Business Day, 2 Sep. Retrieved 28 Dec. 2011 from http://www.businessday.co.za/Articles/Content.aspx?id=119959

44. SSA. (2011). South African listed companies make progress tackling climate change. Retrieved 31 Dec. 2012 from: http://www.sustainabilitysa.org/SustainabilityInvestmentGuidelines/CorporateandInvestor supportgrowsforJSEsSRI.aspx

45. Toyota Motor Corporation. (2012). Toyota Motor Corporation: Key messages sustainability report 2012. Japan. 12p.

46. VW AG. (2011). Volkswagen Aktiengesellschaft Sustainability Report 2011. Germany. 104p. 


\section{ARTICLE ANNEXURE: QUESTIONNAIRE}

Company name:

Interviewee:

Date of interview:

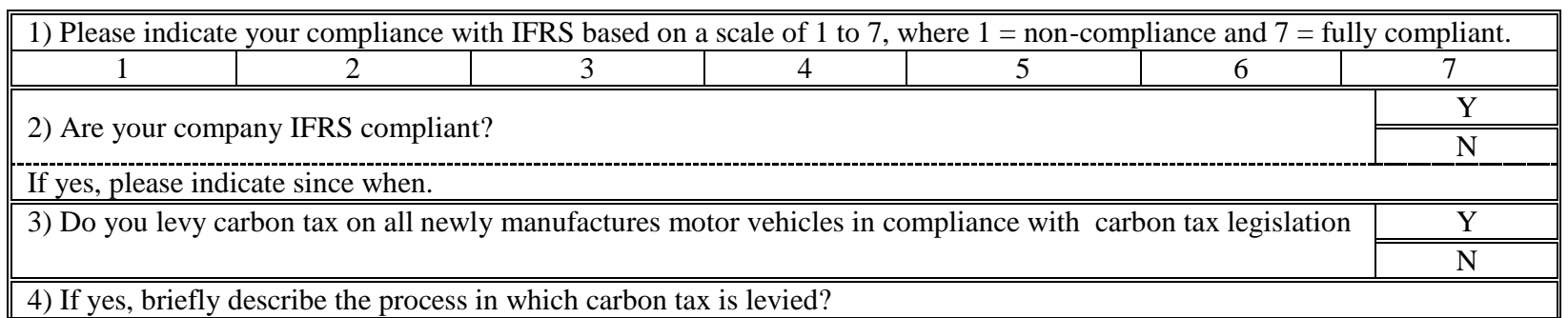

For the Questions 5-7 below, please indicate the frequency of each, based on the following scale:

\begin{tabular}{|c|c|c|c|c|}
\hline 1 & 2 & 3 & 4 & 5 \\
\hline Always & Most of the time & Sometimes & Rarely & Never \\
\hline
\end{tabular}

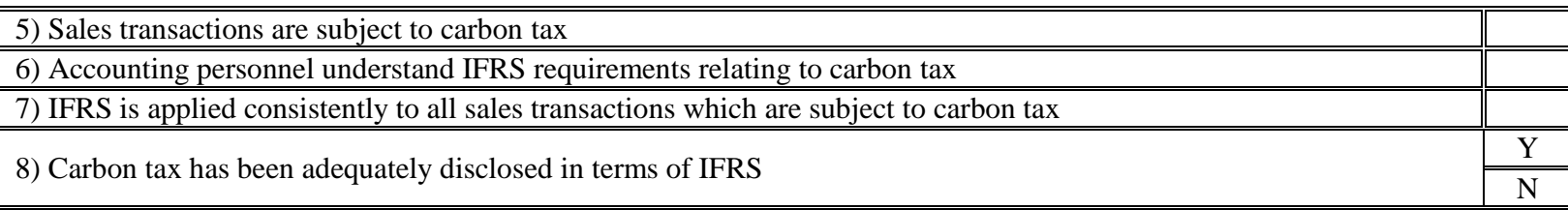

9) Describe the economic substance of carbon tax transactions which determine your accounting treatment of carbon tax transactions?

\begin{tabular}{|l|c||c||}
\hline \hline 10) Provide the journal entries (including narrations) for the recording of carbon excise taxes? & Debit & \multicolumn{1}{|c||}{ Credit } \\
\hline \hline Narration: & Acc Name: & Acc Name: \\
\hline Narration: & Acc Name: & Acc Name: \\
\hline Narration: & Acc Name: & Acc Name: \\
\hline Narration: & Acc Name: & Acc Name: \\
\hline Narration: & Acc Name: & Acc Name: \\
\hline \hline 11) Do you believe that the accounting treatment applied to carbon tax is correct in terms of IFRS? & Y \\
\cline { 2 - 3 } & $\mathrm{N}$ \\
\hline
\end{tabular}

